\title{
Econazole Nitrate
}

National Cancer Institute

\section{Source}

National Cancer Institute. Econazole Nitrate. NCI Thesaurus. Code C47506.

An imidazole derivative and broad-spectrum antimycotic agent with fung istatic properties. Econazole nitrate inhibits biosynthesis of ergosterol, thereby damaging the fung al cell wall membrane and altering its permeability which leads to a loss of essential intracellular components. In addition, econazole nitrate inhibits biosynthesis of triglycerides and phospholipids and inhibits oxidative and peroxidative enzyme activity which may contribute to cellular necrosis and cell death. Econazole nitrate is also active against some gram positive bacteria. This antifungal agent is used in the treatment various dermatomycoses. 